\title{
PENGARUH BEBAN KERJA, LINGKUNGAN KERJA DAN KOMPENSASI TERHADAP KINERJA DOSEN UNIVERSITAS JABAL GHAFUR
}

\author{
Z U L K I F L I \\ Dosen pada Fakultas Ekonomi Universias Jabal Ghafur, Pidie
}

The performance of a lecturer at a university is influenced by several variables. This research was conducted at Jabal Ghafur University using three variables; workload, working environment and compensation towards the performance of the lecturers of Jabal Ghafur University. The objective of the research was to find out the effect of workload, working environment and compensation towards the performance of the lecturers. Data were collected by distributing questionnaires to 120 lecturers of Jabal Ghafur University. Analytical tool used in this study to measure its effect was multiple linear regression analysis. The results showed that simultaneous workload, working environment, and compensation affect the performance of the lecturers and the effect is significant at $5 \% \mathrm{df}$. Correlation of independent variables on the dependent variable was perfect and determination coefficient stated that workload, working environment and compensation revealed that the performance of the lecturers of Jabal Ghafur University was $90.8 \%$. It can be concluded that workload, working environment and compensation had a significant effect and it is suggested that the lecturers should be given opportunity to continue their study to a higher level.

Keywords: Workload, Working Environment, Compensation, Lecturers' Performance 


\section{PENDAHULUAN}

Universitas Jabal Ghafur merupakan institusi yang bergerak di bidang jasa pendidikan. Dalam rangka menghasilkan suatu produk yang berkualitas tentunya harus pula dibutuhkan proses yang baik dan berkualitas, selalu ada upaya untuk menghasilkan lulusan yang memiliki kompetensi meliputi aspek kognitif, afektif maupun psikomotor. Dalam upayanya tersebut, dosen sebagai tenaga pengajar dituntut untuk memiliki kemampuan dan kinerja yang baik. Menurut Wirawan dalam Margiati (2010), konsep kinerja merupakan singkatan dari kinetika energi kerja yang dalam bahasa Inggris adalah performance. Kinerja atau performance adalah keluaran yang dihasilkan oleh fungsi-fungsi atau individu-individu pada suatu pekerjaan atau suatu profesi tertentu. Kinerja yang sering juga disebut sebagai prestasi kerja adalah hasil kerja secara kuantitas dan kualitas yang dicapai seseorang dalam melaksanakan tugas sesuai tanggung jawab yang diberikan pada waktu tertentu. Keberhasilan dosen dalam kegiatan belajar mengajar ditentukan oleh kinerja dosen sebagai tenaga pendidik. Jika kinerja dosen baik maka hasil proses belajar mengajar akan baik pula, sehingga berdampak signifikan terhadap mutu lulusan yang dihasilkan dalam sebuah institusi pendidikan. Kinerja dosen penting dalam mencapai tujuan pembelajaran yang optimal.

Parameter kinerja dosen yang baik tentunya mengacu pada pencapaian hasil pelaksanaan Tri Dharma Perguruan Tinggi. Dan hal inilah yang tampaknya masih belum bisa dicapai oleh dosen yang berada di lingkungan Universitas Jabal Ghafur

Ada tiga prioritas Unigha untuk mencapai visi, misi dan tujuan yang telah ditetapkan yang termaktub dalam Renstra tahun 2011-2015, yaitu memantapkan stabilitas kampus, merealisasikan organisasi yang sehat dan manajemen yang transparan serta meningkatkan kualitas lulusan untuk daya saing nasional. Untuk mencapai ketiga prioritas tersebut ditetapkan lima sasaran dengan berbagai strategi. Adapun sasaran-sasaran tersebut adalah meningkatnya kualitas pembelajaran, meningkatnya kuantitas dan kualitas penelitian dan pengabdian masyarakat serta publikasi ilmiah, kerjasama institusional, tatakelola organisasi dan manajemen yang sehat serta meningkatnya keterampilan lulusan. Saat ini kelima sasaran tersebut sedang dijalankan secara simultan oleh semua organisasi di lingkungan Universitas Jabal Ghafur.

Kegiatan Proses Belajar Mengajar (PBM) meliputi kuliah, praktikum, kuliah umum, tutorial, skripsi, kerja praktek, dan diskusi, yang sesuai dengan kurikulum yang berlaku, dilengkapi dengan kontrak perkuliahan,berita acara kehadiran, berita acara perkuliahan, silabus dan SAP, daftar Referensi / pustaka, diktat/modul kuliah dan praktikum, Peraturan akademik, laboratorium dan perpustakaan, serta SDM. Setiap kehadiran dosen dan mahasiswa dalam perkuliahan dan praktikum, dicatatkan dalam berita acara manual ataupun SIM akademik. Sementara setiap semester diadakan evaluasi penilaian kuliah ataupun praktikum yang terdiri unsur UTS, UAS, kehadiran, tugas, dan unsur penilaian lainnya yang ditentukan oleh dosen pembina mata kuliah. Pelaporan kegiatan akademik dilakukan secara rutin ataupun insidentil, melalui manual ataupun SIM Akademik. Kinerja dari proses pendidikan yang ditawarkan oleh Unigha dapat ditinjau dari beberapa indikator. Dari indikator kelulusan mahasiswa diperoleh gambaran bahwa terdapat peningkatan IPK lulusan untuk Fakultas Keguruan dan Ilmu Pendidikan tiap tahun angkatan dan standar lulusan Unigha empat tahun terakhir (2009- 2012) memang cukup menggembirakan mengalami peningkatan.

Rumusan masalah dari penelitian ini adalah:

1. Bagaimana Beban kerja dosen, berpengaruh terhadap kinerja dosen Universitas Jabal Ghafur.

2. Bagaimana lingkungan kerja berpengaruh terhadap kinerja dosen Universitas Jabal Ghafur.

3. Bagaimana kompensasi berpengaruh terhadap kinerja dosen Universitas Jabal Ghafur.

Penelitian ini bertujuan untuk:

1. Untuk Mengetahui Pengaruh lingkungan kerja terhadap kinerja dosen Universitas Jabal Ghafur.

2. Untuk Mengetahui Pengaruh kompensasi terhadap kinerja dosen Universitas Jabal Ghafur. 


\section{TINJAUAN PUSTAKA}

\section{Beban Kerja}

Definisi beban kerja menurut Tarwaka (Nugraheni, 2009) adalah "setiap pekerjaan merupakan beban bagi yang bersangkutan. Beban tersebut dapat berupa beban fisik maupun mental". Sementara Gunawan (2007:120) mendefinisikan "beban kerja sebagai jumlah pekerjaan yang harus diselesaikan oleh sekelompok atau seseorang dalam waktu tertentu".

Dari berbagai definisi diatas, dapat diambil kesimpulan, beban kerja adalah jumlah pekerjaan yang harus diselesaikan oleh seseorang dalam jangka waktu tertentu. Beban kerja dapat berupa beban fisik maupun mental dapat dipandang dari sudut obyektif dan subyektif.

Dosen adalah salah satu komponen esensial dalam suatu sistem pendidikan di perguruan tinggi. Peran, tugas, dan tanggung jawab dosen sangat penting dalam mewujudkan tujuan pendidikan nasional, yaitu mencerdaskan kehidupan bangsa, meningkatkan kualitas manusia Indonesia, yang meliputi kualitas iman/takwa, akhlak mulia, dan penguasaan ilmu pengetahuan, teknologi, dan seni, serta mewujudkan masyarakat Indonesia yang maju, adil, makmur, dan beradab.

Kompetensi tenaga pendidik, khususnya dosen, diartikan sebagai seperangkat pengetahuan, keterampilan dan perilaku yang harus dimiliki, dihayati, dikuasai dan diwujudkan oleh dosen dalam melaksanakan tugas profesionalnya. Kompetensi tersebut meliputi kompetensi pedagogik, kompetensi kepribadian, kompetensi sosial dan kompetensi profesional. Tugas utama dosen adalah melaksanakan tridharma perguruan tinggi dengan beban kerja paling sedikit sepadan dengan 12 (dua belas) sks dan paling banyak 16 (enam belas) sks pada setiap semester sesuai dengan kualifikasi akademik.

Sedangkan profesor atau guru besar adalah dosen dengan jabatan akademik tertinggi pada satuan pendidikan tinggi dan mempunyai tugas khusus menulis buku dan karya ilmiah serta menyebarkan luaskan gagasannya untuk mencerahkan masyarakat. Pelaksanaan tugas utama dosen ini perlu dievaluasi dan dilaporkan secara periodik sebagai bentuk akuntabilitas kinerja dosen kepada para pemangku kepentingan. Kompetensi dosen menentukan kualitas pelaksanaan Tridharma Perguruan Tinggi sebagaimana yang ditunjukkan dalam kegiatan profesional dosen. Untuk menjamin pelaksanaan tugas dosen berjalan sesuai dengan kriteria yang ditetapkan dalam peraturan

\section{Dampak Beban Kerja}

Nugraheni (2009) menyebutkan bahwa beban kerja memberikan akibat yaitu apabila beban kerja terlalu berat atau kemampuan fisik yang lemah, dapat menyebabkan seorang pekerja menderita gangguan atau penyakit akibat kerja. Sementara menurut Budiono (Nugraheni, 2009), akibat beban kerja fisik yang berat yang berhubungan dengan waktu kerja yang lebih dari 8 jam, maka dapat menurunkan produktivitas kerja serta kondisi sakit.

Menurut Lisnayetti dan Hasan Basri (2006), beban kerja yang tinggi menyebabkan berkurangnya kesempatan dosen dalam mempersiapkan materi, mempersiapkan metode dan media untuk pengajaran. Selain itu, beban kerja yang tinggi juga menyebabkan berkurangnya waktu yang bisa dipakai oleh dosen dalam meningkatkan kemampuan dan pengetahuan individu dosen itu sendiri, seperti kemampuanmenguasai bahasa asing, waktu untuk mempersiapkan dan melaksanakan penelitian dan pengabdian pada masyarakat. Beban kerja yang tinggi juga menyebabkan berkurangnya waktu yang dipakai dosen dalam mendapatkan informasi terkini, baik mengenai perkembangan teknologi, perkembangan teori dan metode terbaru dalam bidang keilmuannya.

\section{Lingkup Beban Kerja Dosen}

Undang-Undang Nomor 14 Tahun 2005 tentang Dosen dan Dosen sebagaimana pasal 72 ayat 1-3 menyebutkan bahwa beban kerja dosen mencakup kegiatan pokok yaitu merencanakan pembelajaran, melaksanakan pembelajaran, melakukan evaluasi pembelajaran, membimbing dan melatih, melakukan penelitian, melakukan tugas tambahan, serta melakukan pengabdian kepada masyarakat. Beban kerja sebagaimana dimaksud sekurang-kurangnya sepadan dengan 12 satuan kredit semester (SKS) dan sebanyak-banyaknya 16 satuan kredit semester. Ketentuan lebih lanjut 
mengenai beban kerja dosen sebagaimana dimaksud pada ayat (1) dan ayat (2) diatur oleh setiap satuan pendidikan tinggi sesuai dengan peraturan perundang- undangan.

Beban kerja dosen merupakan beban (tugas) yang diberikan oleh pimpinan perdosenan tinggi kepada dosen, namun demikian prosedur beban kerja tidak harus selalu "top down", dosen juga diharuskan mencari bebannya sendiri (misalnya melalui penelitian hibah, pembuatan buku ajar dan lain-lain) kemudian memintakan surat tugas untuk kegiatan tersebut agar ketentuan jumlah sks terpenuhi. (Dirjen Dikti, 2010).

Satuan kredit semester (SKS) untuk dosen adalah takaran penghargaan terhadap beban kerja dosen dalam melaksanakan Tridharma Perdosenan Tinggi sebanyak 12 SKS per semester atau setara dengan 36 jam per minggu (BAN PT, 2010).

Beban kerja normal seorang dosen tetap, jika mengacu pada Lampiran II Surat Dirjen Dikti No. 3298/D/T/99 tanggal 29 Desember 1999, perhitungan jumlah jam kerja per minggu secara rasional adalah sebagai berikut :

1. Mengajar/memberi kuliah

SKS (Satuan Kredit Semester) ekuivalen dengan 3 jam pelaksanaan yang terdiri atas 1 jam tatap muka di kelas dan 2 jam persiapan menyusun bahan kuliah.

2. Membimbing mahasiswa menyelesaikan skripsi

Skripsi mempunyai bobot 6 SKS berarti setiap mahasiswa harus menyediakan waktu $6 \times 3=18$ jam per minggu untuk mengerjakan skripsi. Karena sifat skripsi adalah tugas mandiri, maka minimal setiap mahasiswa harus berkonsultasi dengan dosen pembimbing selama 1 jam per minggu.

3. Perwalian mahasiswa :

Beban normal dosen wali adalah 20 orang mahasiswa per semester sehingga dosen mengenal setiap mahasiswa yang dibinanya. Untuk hal tersebut dosen menyediakan waktu minimal 1 jam per minggu untuk konsultasi terhadap masalahmasalah yang dihadapi para mahasiswanya.

4. Menguji ujian akhir/sidang sarjana :

Setiap ujian akhir (sidang sarjana) memakan waktu 3 jam sehingga jika ada 3 mahasiswa mengikuti sidang sarjana pada akhir semester, dosen penguji harus menyediakan waktu 9 jam per semester atau 0,5 jam per minggu ( 1 semester ekuivalen dengan 18 minggu)

5. Membuat diktat kuliah

Diktat kuliah diperkirakan berjumlah 100 halaman dan untuk menjamin mutu diktat yang baik diperlukan waktu menulis yang cukup. Jika 100 halaman ditulis dalam waktu 1 tahun, maka diperkirakan setiap minggu dapat ditulis 2 halaman (50 minggu efektif dalam 1 tahun) dan untuk dapat menulis 2 halaman yang bermutu diperlukan waktu 2 jam (termasuk persiapan mencari literatur, gambar, dsb.)

\section{Penelitian}

Sesuai dengan ketentuan yang berlaku di Direktorat Pembinaan Penelitian dan Pengabdian pada Masyarakat Ditjen Dikti, maka alokasi waktu yang harus disediakan oleh peneliti utama dalam melakukan penelitian Hibah Bersaing (HB) adalah 10 jam per minggu.

7. Penulisan makalah di jurnal terakreditasi

Penulisan makalah yang diterbitkan di jurnal memerlukan waktu cukup lama, dimulai dari penulisan naskah, pengiriman ke dewan redaksi, review oleh tim penilai, perbaikan/koreksi oleh penulis berdasarkan hasil review dan proses penyempurnaan untuk siap cetak. Menurut kaidah nornal, diperlukan waktu 2 tahun dari saat mulai penulisan untuk akhirnya terbit di jurnal, dan waktu yang harus dialokasikan oleh penulis adalah ekuivalen dengan 1 jam per minggu.

8. Pelatihan insidental

Kegiatan ini ditujukan untuk pengabdian pada masyarakat dengan memberikan jasa keahlian yang dimiliki oleh dosen tersebut. Berdasarkan kaidah normal, maka dosen mengadakan pelatihan 1 topik per semester dengan lama waktu pelatihan 3 hari kerja (ekuivalen 18 jam pelatihan). Untuk mempersiapkan bahan pelatihan diperlukan waktu minimal 18 jam, berarti diperlukan waktu 1 jam per minggu (1 semester ekuivalen dengan 18 minggu).

9. Keanggotaan dalam panitia

Keanggotaan dalam panitia memerlukan komitmen waktu minimal untuk menghadiri rapat. Jika rapat rutin diadakan setiap 2 minggu dan setiap rapat normalnya berlangsung 2 jam 
maka diperlukan komitmen untuk 1 jam per minggu. Dari berbagai uraian mengenai beban kerja diatas, dengan mempertimbangkan kondisi pekerjaan riil dan bukti portofolio di lapangan, maka pengertian beban kerja dosen disini adalah beban mengajar atau memberi kuliah di kelas (1 SKS setara dengan 3 jam pelaksanaan, yang terdiri atas 1 jam tatap muka di kelas dan 2 jam persiapan menyusun bahan kuliah), asistensi kuliah atau praktikum di laboratorium (1 SKS setara dengan 2 jam tatap muka), dan membimbing mahasiswa menyelesaikan skripsi atau tugas akhir (1 SKS sama dengan 1 jam tatap muka per minggu).

\section{Lingkungan Kerja}

Lingkungan kerja sangat penting untuk diperhatikan manajemen. Meskipun lingkungan kerja tidak melaksanakan proses produksi dalam suatu Universitas, namun lingkungan kerja mempunyai pengaruh langsung terhadap para Dosen yang melaksanakan proses produksi tersebut. Lingkungan kerja yang memusatkan bagi Dosennya dapat meningkatkan kinerja. Sebaliknya lingkungan kerja yang tidak memadai akan dapat menurunkan kinerja. Sebaliknya lingkungan kerja yang tidak memadai akan dapat menurunkan kinerja dan akhirnya menurunkan motivasi kerja Dosen

Suatu kondisi lingkungan kerja dikatakan baik atau sesuai apabila manusia dapat melaksnakan kegiatan secara optimal, sehat, aman dan nyaman. Kesesuaian lingkungan kerja dapat dilihat akibatnya dalam jangka waktu yang lama. Lebih jauh lagi lingkungan-lingkungan kerja yang kurang baik dapat menuntut tenaga kerja dan waktu yang lebih banyak dan tidak mendukung diperolehnya rencangan ystem kerja yang efisien.

Nitisemito (2000:183) mendifinisikan lingkungan kerja antara lain sebagai berikut, "lingkungan kerja adalah segala sesuatu yang ada disekitar para pekerja yang dapat mempengaruhi dirinya dalam menjalankan tugas-tugas yang diembankan".

Sedarmayati (2001:1) mendefinisikan lingkungan kerja sebagai berikut, "lingkungan kerja adalah keseluruhan alat perkakas dan bahan yang dihadapi, lingkungan sekitarnya di mana seseorang bekerja, metode kerjanya, serta pengaturan kerjanya baik sebagai perseorangan maupun sebagai kelompok".
Dari beberapa pendapat di atas, disimpulkan bahwa lingkungan kerja merupakan segala sesuatu yang ada di sekitar Dosen pada saat bekerja, baik yang berbentuk fisik ataupun non fisik, langsung atau tidak langsung, yang dapat mempengaruhi dirinya dan pekerjaanya saat bekerja.

Sedarmayanti (2001:21) menyatakan bahwa secara garis besar, jenis lingkungan kerja terbagi menjadi 2 yakni : a) lingkungan kerja fisik, dan b) lingkungan kerja non fisik. Adapun penjelasan masing-masing dapat dilihat dibawah ini :

1. Lingkungan kerja fisik

Menurut Sedarmayanti (2001:21), “lingkungan kerja fisik adalah semua keadaan berbentuk fisik yang terdapat di sekitar tempat kerja yang dapat mempengaruhi Dosen baik secara langsung maupun scara tidak langsung." Lingkungan kerja fisik dapat dibagi dalam dua kategori, yakni :

Lingkungan yang langsung berhubungan dengan Dosen (seperti: pusat kerja, kursi, meja dan sebagainya)

Lingkungan perantara atau lingkungan umum dapat juga disebut lingkungan kerja yang mempengaruhi kondisi manusia, misalnya, temperatur, kelembaban, sirkulasi udara, pencahayaan, kebisingan, getaran mekanis, bau tidak sedap, warna dan lain-lain.

Untuk dapat memperkecil pengaruh lingkungan fisik terhadap Dosen, maka langkah pertama adalah harus mempelajari manusia, baik mengenai fisik dan tingkah lakunya maupun mengenai fisiknya, kemudian digunakan sebagai dasar memikirkan lingkungan fisik yang sesuai.

\section{Lingkungan Kerja Non Fisik}

Menurut Sadarmayanti (2001:31), "lingkungan kerja non fisik adalah semua keadaan yang terjadi yang berkaitan dengan hubungan kerja, baik hubungan dengan atasan maupun hubungan sesama rekan kerja, ataupun hubungan dengan bawahan".

Lingkungan non fisik ini juga merupakan kelompok lingkungan kerja yang tidak bisa diabaikan.

Menurut Nitisemito (2000:171-173) Universitas hendaknya dapat mencerminkan kondisi yang mendukung kerja sama antara tingkat atasan, bawahan maupun yang memiliki status jabatan yang sama di Universitas. Kondisi yang hendakn- 
ya diciptakan adalah suasana kekeluargaan, komunikasi yang baik, dan pengendalian diri.

Sentoso (2001:19-21), menyatakan pihak manajemen hendaknya membangun suatu iklim dan suasana kerja yang bisa membangkitkan rasa kekeluargaan untuk mencapai tujuan bersama. Pihak manajemen Universitas juga hendaknya mampu mendorong inisiatif dan kreativitas. Kondisi seperti inilah yang selanjutnya menciptakan antusiasme untuk bersatu dalam organisasi Universitas untuk mencapai tujuan.

Berikut ini beberapa faktor yang diuraikan Sedarmayanti (2001:21) yang dapat mempengaruhi terbentuknya suatu kondisi lingkungan kerja dikaitkan dengan kemampuan Dosen, diantaranya adalah:

a. Penerangan/cahaya di tempat kerja

b. Temperatur/suhu udara di tempat kerja

c. Kelembaban di tempat kerja

d. Sirkulasi udara di tempat kerja

e. Kebisingan di tempat kerja

f. Getaran mekanis di tempat kerja

g. Bau tidak sedap ditempat kerja

h. Tata warna di tempat kerja

i. Dekorasi di tempat kerja

j. Musik di tempat kerja

k. Keamanan di tempat kerja

\section{Kompensasi}

Penetuan tingkat kompensasi penting bagiuniversitas, karena upah atau gaji seringkali merupakan satu-satunya biaya terbesar bagi universitas. Hal ini juga penting bagi dosen, karena uang gaji merupakan sumber pendapatan untuk kelangsungan hidup dosen dan merupakan salah satu faktor yang berpengaruh dalam menetukan status ditengah masyarakat.

Handoko (2002:150) menyatakan bahwa : "kompensasi adalah pemberian kepada Dosen dengan pembayaran finansial sebagai balas jasa untuk pekerjaan yang dilaksanakan dan sebagai motivator untuk pelaksanaan kegiatan di waktu yang akan datang”.

Menurut Flippo (1996:46), program kompensasi dirancang untuk melakukan tiga hal yaitu: a) Untuk menarik dosen yang cakap dalam universitas. b). Untuk memotivasi dosen untuk meraih prestasi yang tinggi. c). Untuk menciptakan masa dinas yang panjang.

Harapan untuk mendapatkan kompensasi yang lebih baik menjadikan adanya kecenderungan seseorang mengajar dengan baik. Kompensasi yang baik mengandung unsur yang punya rasa keadilan, keseimbangan, keserasian, dan kewajaran dari kedua belah pihak yaitu antara dosen, Universitas dan yayasan. Mulyasa (2004:156) pengertian kompensasi "balas jasa yang diberikan dinas pendidikan danuniversitas kepada tenaga kependidikan, yang dapat dinilai dengan uang dan mempunyai kecendrungan diberikan secara tetap".

Berdasarkan pengertian diatas dapat diambil kesimpulan bahwa kompensasi itu merupakan suatu penghargaan yang di berikan kepada para tenaga pengajar secara adil dan layak, yang di maksud untuk prestasi kerja dosen yang telah dikeluarkan demi tercapainya tujuan Universitas.

\section{Tujuan Pemberian Kompensasi}

Tujuan pemberian kompensasi (balas jasa) menurut Handoko (2002:150) adalah:

1. Memperoleh personalia yang berkualitas

Kompensasi perlu ditetapkan cukup tinggi agar menarik para pelamar, karena organisasiorganisasi bersaing dalam pasar tenaga kerja, tingkat pengupahan harus sesuai dengan kondisi suplai dan permintaan tenaga kerja. Terkadang tingkat gaji yang relative tinggi diperlukan untuk menarik para pelamar yang cakap dan sudah bekerja di berbagai organisasi lain.

2. Mempertahankan para pekerja yang ada sekarang

Bila tingkat kompensasi tidak kompetitif, niscaya banyak tenaga dosen yang baik akan keluar. Untuk mencegah perputaran dosen, pengupahan harus dijaga agar tetap kompetitif denganuniversitas lain.

3. Menjamin keadilan

Administrasi pengupahan dan penggajianuniversitas untuk memenuhi prinsip keadilan. Keadilan dan konsisten internal dan eksternal sangat penting diperhatikan dalam tingkat kompensasi.

4. Kepuasan kerja

Dengan balas jasa dosen akan dapat memenuhi kebutuhan-kebutuhan fisik, status, social dan egoistiknya, sehingga ia memperoleh kepua- 
san kerja dari jabatannya itu.

5. Motivasi

Jika balas jasa yang di berikan cukup besar, Rektor akan mudah memotivasi bawahannya.

6. Disiplin

Dengan pemberian balas jasa yang cukup besar maka disiplin dosen semakin baik. Mereka akan menyadari serta mentaati peraturan-peraturan yang berlaku. Tujuan pemberian balas jasa ini hendaknya memberikan kepuasan kepada semua pihak, dosen dapat memnuhi kebutuhannya, Rektormendapatkan hasil yang baik, peraturan pemerintah harus ditati, dan masyarakat mendapatkan hasil yang baik, tamatan yang membanggakan.

\section{Prosedur Evaluasi Dan Pengukuran Kinerja Dosen}

Prosedur evaluasi kinerja dosen merupakan pedoman bagi seluruh dosen Universitas Jabal Ghafur dalam rangka mengukur dan menindak lanjuti kinerja dosen melalui kebijakan penetapan Reward dan Punishment, melaui prosedur ini diharapkan proses evaluasi kinerja lebih terstruktur dan terarah, sehingga kinerja dosen Universitas Jabal Ghafur akan meningkat., langkah Peningkatan dan Evaluasi kinerja dosen sebagai berikut:

1. Evaluasi kinerja dosen adalah proses mengidentifikasi, mengukur, melaporkan, menganalisis, dan memberikan feedback atas kinerja dosen selama periode waktu tertentu, minimal 1 kali per semester.

2. Sasaran evaluasi kinerja dosen adalah dosen penuh waktu dan dosen paruh waktu di Universitas Jabal Ghafur.

3. Parameter kinerja dosen penuh waktu minimal, sebagai berikut :
a. Aspek pengajaran
b. Aspek pembimbingan
c. Aspek publikasi, riset, dan pengabdian masyarakat
d. Aspek partisipasi kegiatan Progam Studi/ Fakultas dan Universitas

4. Parameter kinerja dosen paruh waktu minimal memenuhi aspek pengajaran

5. Parameter kinerja dosen diatur dalam ketentuan Reward dan Punishment

6. Unit Penjaminan Mutu melakukan pengolahan dan analisa data, dengan mendapatkan supporting data dari fakultas dan LPPM.

7. Hasil evaluasi kinerja dosen harus dijadikan dasar untuk penentuan kebijakan Progam Studi secara umum maupun secara individu dosen yang bersangkutan.

8. Pemberian Reward dan Punishment atas hasil evaluasi kinerja dosen adalah kewenangan dari Rektor, berdasarkan data dari Unit Penjaminan Mutu.

\section{METODE PENELITIAN}

Adapun Tempat penelitian dilakukan di Kota Sigli, dan yang menjadi objek penelitian ini terbatas pada beban kerja, lingkungan kerja dan kompensasi terhadap kinerja dosen pada Universitas Jabal Ghafur.

\section{Populasi Dan Sampel}

Populasi penelitian adalah dosen Kopertis dpk Universitas Jabal Ghafur dan dosen tetap Yayasan Universitas Jabal Ghafur yang berjumlah 270 orang. Adapun untuk menentukan jumlah sampel, penulis menggunakan rumus Slovin (Arikunto, 2003), sebagai berikut :

$$
n=\frac{N}{1+N d^{2}}
$$

Dimana:

$\mathrm{n}=$ Besar sampel

$\mathrm{N}=$ Jumlah populasi

$\mathrm{d}=$ derajat kepercayaan (ditetapkan 10\%)

Sehingga :

$$
\begin{aligned}
& n=\frac{270}{1+270(0,0)} \\
& =99,93 \text { (dibulatkan menjadi 100) }
\end{aligned}
$$

Dari hasil perhitungan diatas, maka jumlah sampel yang diambil untuk penelitian ini adalah sebanyak 100 orang dosen.

\section{Teknik Penarikan Sample}

Penentuan sampel menggunakan metode stratified random sampling, yaitu metode penarikan sampel secara acak berstrata atau berjenjang. 
Adapun sampel penelitian ini terbagi kepada 270 orang dosen yang mengajar di 20 program studi di Universitas Jabal Ghafur.

\section{Metode Pengumpulan Data}

Data yang diolah dalam rangka pengujian hipotesis berupa data primer yang diperoleh dari hasil tanggapan responden atas daftar pertanyaan (kuesioner) yang bersifat tertutup yang disebarkan kepada responden. Selanjutnya untuk mendukung penelitian, penulis juga mengumpulkan data sekunder berupa dokumentasi, jurnal ilmiah, referensi dan bahan lainnya yang berkaitan.

\section{Peralatan Analisis Data}

Untuk menjelaskan pengaruh variabel bebas terhadap variabel terikat, digunakan model regresi linier berganda yaitu:

$$
\boldsymbol{Y}=\alpha+\beta_{1} \boldsymbol{X}_{1}+\beta_{2} \boldsymbol{X}_{2}+\beta_{3} \boldsymbol{X}_{3}+\boldsymbol{e}
$$

Dimana:

$Y=$ Kinerja Dosen Universitas Jabal Ghafur

$X_{I}=$ Faktor Beban Kerja

$X_{2}=$ Faktor Lingkungan Kerja

$X_{3}=$ Faktor Kompensasi

$\alpha=$ Konstanta

$\beta_{l}, \beta 2, \beta 3=$ Koefisien regresi variabel $\mathrm{X}_{1,2,3}$ $e=$ Standart error

\section{HASIL DAN PEMBAHASAN}

\section{Analisis Tanggapan Responden Terhadap Pengaruh Beban Kerja, Lingkungan Kerja, Dan Kompensasi terhadap Kinerja Dosen Universitas Jabal Ghafur}

Berdasarkan hasil penyebaran kuisioner yang menyangkut dengan pengaruh beban kerja, lingkungan kerja, dan kompensasi terhadap kinerja dosen Universitas Jabal Ghafur Sigli terhadap 120 orang staf pengajar yang tersebar pada fakultas-fakultas dilingkungan dilingkungan Universitas Jabal Ghafur Sigli, dimana Pengaruh beban kerja, lingkungan kerja, dan kompensasi berpengaruh terhadap kinerja dosen Universitas Jabal Ghafur Sigli. Untuk mengukur variabel-variabel yang mempengaruhi kinerja staf pengajar pada Universitas Jabal Ghafur Sigli dengan mengguna- kan 3 indikator dan distribusi frekuensi jawaban responden terhadap variabel yang mempengaruhi kinerja staf pengajar

dapat dijelaskan bahwa variabel nilai dalam penelitian ini rerata sebesar 3,614 yang bermakna bahwa responden dalam penelitian ini merasa sangat setuju bahwa variabel beban kerja berpengaruh terhadap kinerja dosen pada Universitas Jabal Ghafur. Hal ini dapat dilihat dari beberapa pernyataan responden menulis modul/diktat/bahan ajar tidak diterbitkan, tetapi digunakan oleh mahasiswa tergolong baik hal ini dapat dilihat dari nilai rata-rata sebesar 3,5417. kemudian pernyataan responden kemampuan mengendalikan diri dalam berbagai situasi dan kondisi dilihat dari nilai rata-rata sebesar 3,6167, dan kemampuan menerima kritik, saran, dan pendapat orang lain dengan nilai rata-rata sebesar 3,8583 pada skala likert.

Disamping pernyataan itu, ada pernyataan lain yang mengindikasikan bahwa beban kerja dapat berpengaruh terhadap kinerja dosen dilingkungan Universitas Jabal Ghafur dapat dilihat dari pernyataan mengenai menjadi contoh dalam bersikap dan berperilaku dengan tergolong baik dengan diperoleh nilai rata-rata sebesar 3,9250 sedangkan pernyataan membuat dan menjelaskan kontrak belajar pada awal pertemuan mengenai sangat setuju diperoleh nilai rata-rata sebesar 3,2083 yang merupakan nilai rata-rata terendah dari variabel beban kerja pada Universitas Jabal Ghafur.

\section{Variabel Lingkungan Kerja}

Lingkungan kerja Universitas Jabal Ghafur diidentifikasikan pengaruhnya dengan mengajukan 19 buah statemen

Dimana variabel lingkungan kerja dalam penelitian ini rerata sebesar 3,660 yang bermakna bahwa responden dalam penelitian ini merasa setuju bahwa lingkungan kerja Universitas Jabal Ghafur dapat berpengaruh kinerja dosen. Hal ini dapat dilihat dari pernyataan responden mengenai dekorasi ditempat kerja membuat anda nyaman diketahui nilai rerata sebesar 4.1667 , artinya responden merasa keyamanan dalam bekerja sebagai akibat adanya dekorasi yang baik di tempat kerja.

Sebaliknya dilihat dari pernyataan fasilitas pembelanjaran seperti komputer, infokus/LCD 
sangat membantu dalam mengajar dengan rerata 3,233, kondisi seperti ini menunjukkan bahwa fasilitas dimaksud masih belum dirasakan keberadaanya

\section{Variabel Kompensasi}

Kompensasi sebagai imbalan yang diterima atas suatu kegiatan dosen menjadi sangat penting dan mempunyai pengaruh terhadap kinerja, untuk medeteksi penilaian responden terhadap adanya kompensasi dilingkungan Universitas Jabal Ghafur dapat dijelaskan bahwa dari keseluruhan pernyataan responden menyatakan bahwa kompensasi yang diterima oleh masing-masing telah baik dan cenderung sangat baik, di mana responden menjawab pada rerata di atas 3, sehingga untuk itu dapat dilihat rerata tertinggi pada pernyataan rerata 4,2750, hal ini menggambarkan bahwa honor menguji telah diberikan sangat sesuai dengan yang diharapkan.

Selanjutnya pernyataan honor yang diterima sudah sesuai dengan jumlah SKS yang diemban rerata 3,2750, sebenarnya jenis honor ini telah cukup baik, tetapi belum dapat menyamai dengan jenis-jenis honor lainnya.

\section{Kinerja Dosen}

Kinerja dosen pada Universitas Jabal Ghafur yang mendapat tanggapan oleh responden terhadap 36 pernyaaan dapat dijelaskan bahwa responden mengapresiasikan pernyataan keluasan wawasan berilmu dan penguasaan bidang keahlian yang menjadi tugas pokok pada rerata 4,2917, hal ini menunjukkan bahwa dosen Universitas Jabal Ghafur memiliki wawasan berfikir yang luas dengan sangat menguasai kelimuan dibidangnya.

Sebaliknya dilihat pada pernyataan menerjemahkan atau menyadur satu judul naskah buku yang akan diterbitkan dalam waktu sebanyak-banyaknya 4 semester mendapat skor rerata 3,2833, dengan demikian para dosen masih belum lebih baik kinerjanya dibidang penerjemahan dan penyaduran buku.

Kinerja dosen Universitas Jabal Ghafur atau staf pengajar secara rinci berdasarkan tititk maksimum dan minimum dapat dilihat indikator dari kinerja dosen sebagaimana yang dijelaskan pada Tabel 1.
Berdasarkan Tabel 1, dapat dijelaskan bahwa secara rerata, kinerja dosen Universitas Jabal Ghafur telah baik dengan skor 3,72 dan angka rerata minimum sebesar 3,20, sedangkan angka rerata tertinggi sebesar 4,38, sehingga dapat disimpulkan bahwa kinerja dosen Universitas Jabal Ghafur telah baik.

\section{Analisis Pengaruh Beban Kerja, Lingkungan Kerja, Kompensasi Terhadap Kinerja Dosen Universitas Jabal Ghafur}

Seperti yang dikemukakan pada perumusan masalah dan hipotesis, penelitian ini menganalisis pengaruh Beban Kerja $\left(\mathrm{X}_{1}\right)$, Lingkungan Kerja $\left(\mathrm{X}_{2}\right)$, Kompensasi $\left(\mathrm{X}_{3}\right)$ terhadap kinerja dosen Universitas Jabal Ghafur sebagai variabel terikat (dependent variabel) baik secara simultan maupun parsial.

Dalam rangka meningkatkan kinerja dosen di Universitas Jabal Ghafur maka perlu diketahui pengaruh variabel bebas yang dapat berpengaruh terhadap kinerja dosen yaitu beban kerja $\left(\mathrm{X}_{1}\right)$, Lingkungan kerja $\left(\mathrm{X}_{2}\right)$, Kompensasi $\left(\mathrm{X}_{3}\right)$ terhadap kinerja dosen Universitas Jabal Ghafur. Pengaruh masing-masing variabel bebas terhadap variabel terikat secara terinci dapat dilihat pada Tabel 2.

Dari hasil perhitungan statistik dengan menggunakan bantuan program SPSS seperti terlihat pada tabel di atas, maka diperoleh persamaan regresi berganda sebagai berikut :

$$
Y=0,536+0,222 X_{2}+0,280 X_{2}+0,252 X_{3}+e
$$

Dari persamaan regresi di atas dapat diketahui bahwa konstanta sebesar 0,536 , artinya jika beban kerja $\left(\mathrm{X}_{1}\right)$, lingkungan kerja $\left(\mathrm{X}_{2}\right)$ dan kompensasi $\left(\mathrm{X}_{3}\right)$ dianggap konstanta, maka besarnya kinerja dosen adalah sebesar 5,36 persen, hal ini diartikan dengan perubahan variabel independen sebesar 1 persen, maka akan meningkatkan kinerja dosen Universitas Jabal Ghafur sebesar 5,36 persen.

\section{Koefisien Regresi (b)}

Konstanta sebesar 0,536, artinya jika factor beban kerja $\left(\mathrm{X}_{1}\right)$, lingkungan kerja $\left(\mathrm{X}_{2}\right)$ dan kompensasi $\left(\mathrm{X}_{3}\right)$ dianggap konstan, maka besarnya prestasi kerja Universitas Jabal Ghafur adalah sebesar 53,6 persen, artinya prestasi kinerja dosen 
Tabel 1

Kinerja Staf Pengajar (Dosen)

\begin{tabular}{lc}
\hline $\mathrm{N} \quad$ Valid & 120 \\
\hline \multicolumn{1}{c}{ Missing } & - \\
\hline Mean [Nilai rata-rata] & 3,72 \\
\hline Std. Deviation (Standar Penyimpangan Baku) & 0,236 \\
\hline Minimum [Nilai Terendah] & 3,20 \\
\hline Maximum [Nilai Tertinggi] & 4,38 \\
\hline
\end{tabular}

Tabel 2

Pengaruh Masing-Masing Variabel Bebas Terhadap Variabel Terikat

\begin{tabular}{|l|c|}
\multicolumn{1}{|c|}{$\begin{array}{c}\text { Nama } \\
\text { Variabel }\end{array}$} & B \\
Konstata & 0,536 \\
Beban kerja $\left(\mathrm{X}_{1}\right)$ & 0,222 \\
Lingkungan kerja $\left(\mathrm{X}_{2}\right)$ & 0,280 \\
Kompensasi $\left(\mathrm{X}_{3}\right)$ & 0,352
\end{tabular}

\begin{tabular}{c|c|c|c|}
\begin{tabular}{c|c|} 
Standar \\
Error
\end{tabular} & $\mathbf{t}_{\text {hitung }}$ & $\mathbf{t}_{\text {tabel }}$ & Sig \\
0,114 & 4,686 & 1,960 & 0.000 \\
0,023 & 9,628 & 1,960 & 0.000 \\
0,026 & 10,733 & 1,960 & 0.000 \\
0,023 & 15,025 & 1,960 & 0.000
\end{tabular}

Sumber : Data Primer, 2013 (diolah)

Universitas Jabal Ghafur prestasi kerja dikatakan baik.

Koefisien regresi beban kerja $\left(\mathrm{X}_{1}\right)$ sebesar 0,222 artinya bahwa setiap $100 \%$ perubahan (perbaikan, karena tanda + ) dalam variabel beban kerja maka secara relatif akan meningkatkan kinerja dosen Universitas Jabal Ghafur sebesar 2,22 persen.

Koefisien regresi lingkungan kerja $\left(\mathrm{X}_{2}\right)$ sebesar 0,280 artinya bahwa setiap $100 \%$ perubahan variabel lingkungan kerja maka secara relatif akan meningkatkan kinerja dosen Universitas Jabal Ghafur sebesar 2,80 persen.

Koefisien regresi kompensasi $\left(\mathrm{X}_{3}\right)$ sebesar 0,352 artinya bahwa setiap $100 \%$ perubahan dalam variabel kompensasi maka secara relatif akan meningkatkan kinerja dosen Universitas Jabal Ghafur sebesar 3,52 persen.

Berdasarkan hasil analisis di atas dapat diketahui bahwa dari ketiga variabel yang diteliti, ternyata variabel beban kerja $\left(\mathrm{X}_{1}\right)$, lingkungan kerja $\left(\mathrm{X}_{2}\right)$ dan kompensasi $\left(\mathrm{X}_{3}\right)$ berpengaruh terhadap kinerja dosen, hal ini mengindikasikan bahwa kinerja dosen Universitas Jabal Ghafur dapat meningkatkan kinerjanya.

Koefisien korelasi ${ }^{\circledR}=0,950$ yang menunjukkan bahwa derajat hubungan (korelasi) antara asi had bebas beban kerja $\left(X_{1}\right)$, lingkungan kerja $\left(X_{2}\right)$ dan kompensasi $\left(\mathrm{X}_{3}\right)$ dengan asi had terikat $\mathrm{Y}(\mathrm{ki}$ nerja dosen) sebesar 95\%, artinya kinerja dosen Universitas Jabal Ghafur cukup kuat.
Koefisien Determinasi $\left(\mathrm{R}^{2}\right)$ sebesar 0,902, artinya sebesar 90,2\% perubahan-perubahan dalam variabel terikat (beban kerja $\left(\mathrm{X}_{1}\right)$, lingkungan kerja $\left(\mathrm{X}_{2}\right)$, dan kompensasi $\left(\mathrm{X}_{3}\right)$ terhadap kinerja dosen Universitas Jabal Ghafur, dapat dijelaskan sebesar 90,2 persen. Sedangkan selebihnya yaitu sebesar $0,98 \%$ dijelaskan oleh faktor-faktor variabel lain diluar daripada penelitian ini, artinya asi hada $0,98 \%$ lagi prestasi kinerja dosen Universitas Jabal Ghafur dipengaruhi oleh faktor lain, diluar penelitian ini yang keberadaannya sulit untuk diprediksi.

Hasil pengujian secara simultan diperoleh $\mathrm{F}_{\mathrm{hi}}$ tung sebesar 356,413, sedangkan $\mathrm{F}_{\text {tabel }}$ pada tingkat signifikansi $\mu=5 \%$ adalah sebesar 2,666. Hal ini memperlihatkan bahwa $\mathrm{F}_{\text {hitung }}>\mathrm{F}_{\text {tabel }}$, dengan tingkat probabilitas 0.000 . Dengan demikian hasil perhitungan ini dapat diambil suatu keputusan bahwa menerima hipótesis alternatif dan menolak hipotesis nol, artinya bahwa variabel beban kerja $\left(\mathrm{X}_{1}\right)$, lingkungan kerja $\left(\mathrm{X}_{2}\right)$, kompensasi $\left(\mathrm{X}_{3}\right)$ terhadap kinerja dosen Universitas Jabal Ghafur secara bersama-sama berpengaruh secara signifikan terhadap kinerja dosen Universitas Jabal Ghafur.

Dengan demikian terbukti bahwa terdapat pengaruh yang signifikan antara variabel beban kerja $\left(\mathrm{X}_{1}\right)$, lingkungan kerja $\left(\mathrm{X}_{2}\right)$, kompensasi $\left(\mathrm{X}_{3}\right)$ terhadap kinerja dosen Universitas Jabal Ghafur, dengan demikian hipotesis alternatif (Ha) yang diajukan diterima dan menolak hipotesis nol (Ho), karena diperoleh pengelolaan proses belajar 
$\mathrm{F}_{\text {hitung }}>\mathrm{F}_{\text {tabel }}$, dengan tingkat probabilitas 0.000 dimana dapat diketahui besarnya $t_{\text {hitung }}$ untuk masing-masing variabel dengan tingkat kepercayaan atau signifikansi sebesar $\alpha=5 \%$.

Hasil penelitian terhadap beban kerja $\left(\mathrm{X}_{1}\right)$ dimana thitung sebesar 9,628, sedangkan $t_{\text {tabel }}$ sebesar 1,960, hasil perhitungan ini menunjukkan bahwa $t_{\text {hitung }}>t_{\text {tabel }}$ dengan signifikansi sebesar 0.000 atau probabilitas jauh dibawah a $=5 \%$. Dengan demikian hasil perhitungan statistik menunjukkan bahwa secara parsial variabel beban kerja $\left(\mathrm{X}_{1}\right)$ berpengaruh secara signifikan terhadap kinerja dosen Universitas Jabal Ghafur. Dengan demikian hipotesis Ha1 diterima bahwa beban kerja secara parsial berpengaruh positif terhadap kinerja dosen Universitas Jabal Ghafur.

Hasil penelitian terhadap lingkungan kerja $\left(\mathrm{X}_{2}\right)$ di mana thitung sebesar 10,733 sedangkan $\mathrm{t}_{\text {ta- }}$ bel sebesar 1,960. Hasil perhitungan ini menunjukkan bahwa $t_{\text {hitung }}>t_{\text {tabel }}$ dengan signifikansi sebesar 0.000 atau probabilitas jauh dibawah a $=5 \%$. Dengan demikian hasil perhitungan statistik menunjukkan bahwa secara parsial variabel lingkungan kerja $\left(\mathrm{X}_{2}\right)$ berpengaruh secara signifikan terhadap kinerja dosen Universitas Jabal Ghafur. Dengan demikian hipotesis Ha1 diterima bahwa lingkungan kerja secara parsial berpengaruh positif terhadap kinerja dosen Universitas Jabal Ghafur.

Hasil penelitian terhadap kompensasi $\left(\mathrm{X}_{3}\right)$ di mana thitung sebesar 15,025 , sedangkan $t_{\text {tabel }}$ sebesar 1,960. Hasil perhitungan ini menunjukkan bahwa $t_{\text {hitung }}>t_{\text {tabel }}$ dengan signifikansi sebesar 0.000 atau probabilitas jauh dibawah a $=5 \%$. Dengan demikian hasil perhitungan statistik menunjukkan bahwa secara parsial variabel kompensasi $\left(\mathrm{X}_{3}\right)$ berpengaruh secara signifikan terhadap kinerja dosen Universitas Jabal Ghafur. Dengan demikian hipotesis Hal diterima bahwa kompensasi secara parsial berpengaruh positif terhadap kinerja dosen Universitas Jabal Ghafur.

\section{KESIMPULAN}

Berdasarkan hasil penelitian dan pembahasan yang telah dianalisis, berikut disimpulkan :
1. Uji statistik $F$ diketahui $F_{\text {hitung }}$ sebesar 356,413 , jauh lebih besar dibandingkan dengan $\mathrm{F}_{\text {tabel }}$ sebesar 2,666. Hal ini menunjukkan bahwa beban kerja $\left(\mathrm{X}_{1}\right)$, lingkungan kerja $\left(\mathrm{X}_{2}\right)$, kompensasi $\left(\mathrm{X}_{3}\right)$ secara bersama-sama mempengaruhi kinerja dosen Universitas Jabal Ghafur, pengaruh tersebut signifikan di mana probabilitas signifikan pada $\mathrm{df}=0,05$ didapati sebesar 0,000

2. Terdapat korelasi sempurna antara beban kerja $\left(\mathrm{X}_{1}\right)$, lingkungan kerja $\left(\mathrm{X}_{2}\right)$, kompensasi $\left(\mathrm{X}_{3}\right)$ terhadap kinerja dosen Universitas Jabal Ghafur, dimana nilai $\mathrm{R}=0,950$ korelasi yang sempurna tersebut merupakan sebuah gambaran betapa besarnya keterkaitan antara beban kerja, ling,kungan kerja dan kompensasi dengan kinerja dosen.

3. Koefisien determinasi sebesar 0,902 memberi arti bahwa setiap perubahan pada beban kerja $\left(\mathrm{X}_{1}\right)$, lingkungan kerja $\left(\mathrm{X}_{2}\right)$, dan kompensasi $\left(\mathrm{X}_{3}\right)$ sebesar 1 persen, maka perubahan tersebut dapat dijelaskan oleh ketiga variabel independen sebesar 90,2 persen, sedangkan 9,8 persen lainnya dijelaskan oleh variabel lain yang tidak diteliti pada penelitian ini.

\section{SARAN}

1. Telah diketahui bahwa beban kerja $\left(X_{1}\right)$, lingkungan kerja $\left(\mathrm{X}_{2}\right)$, dan kompensasi $\left(\mathrm{X}_{3}\right)$ secara simultan mempengaruhi kinerja dosen Universitas Jabal Ghafur, dari sisi parsial, beban kerja belum cukup tinggi mempengaruhi kinerja maka disarankan agar beban kerja yang harus dilaksanakan para dosen dapat diseleraskan dengan kondisi yang benar-benar riel.

2. Untuk mengupayakan peningkatan kinerja dosen kearah yang lebih tinggi diperlukan adanya peningkatan fasilitas dosen, seperti peningkatan kompetensi dosen melalui jenjang pendidikan formal pada strata yang lebih tinggi, mengikuti seminar-seminar pada level nasional ataupun internasional, wookshop kepakaran bidang studi pada universitas yang lebih tinggi statusnya. 


\section{REFERENSI}

, 2010, Buku Pedoman Sertifikasi Pendidik Untuk Dosen Tahun 2010, Buku II dari http://www. serdos.barawijaya.ac.id , 2010, Pedoman Beban Kerja Dosen dan Evaluasi Pelaksanaan Tridharma Perguruan Tinggi Buku I diambil dari http://www.serdos.brawijaya.ac.id

Arikunto, S. 1998, Prosedur Penelitian Suatu Pendekatan Praktek, Reneka Cipta, Yogyakarta

Bernardin, H. John dan Russell, Joyce E.A. 1988, Human Resource Management: An Experienital Approach 2th Edition, Singapore. McGraw-Hill Book Co

Chairy, L.S. 2005, Evaluasi Dosen Sebagai Bentuk dari Penilaian Kinerja, C.V. Mandar Maju

Dirjen Dikti, 2010, Buku Pedoman Sertifikasi Pendidik Untuk Dosen Tahun

Flippo, Edwin B, 1996, Personnel Psychology, 6th Edition, Singapore, McGraw Hill

Gunawan, 2007, Analisis Beban Kerja Perawat dengan Time and Motion Study berdasarkan Kompetensi Perawat. Skripsi. Fakultas Kesehatan Masyarakat, Universitas Airlangga, tidak diterbitkan.

Handoko, T. Hani, 2002, Manajemen Personalia dan Sumber Daya Manusia, Yogyakarta : BPFE

Handoko, 2005, Manajemen Edisi II, Badan Penerbit Fakultas Ekonomi Gravindo, Jakarta

Kep. Men.Diknas, 2001, Petunjuk Teknis Pelaksanaan Angka Kredit Jabatan Fungsional Dosen, Jakarta

Lesnayettu dan Hasan Basri, M, 2006, Beban Kerja dan Kinerja Dosen Poltekes Makalah, Disampaikan dalam Workshop Evaluasi Kinerja Dosen oleh Mahasiswa, di UIN Syarif Hidayatullah : Jakarta, tanggal 9 April, diambil tanggal 30 Maret 2010 dari http://www.staff.ui.ac.id.

Mangkunegara, AP. 2006, Evaluasi Kinerja Sumber Daya Manusia, Refika Aditama, Bandung

Mangkunegara, AP. 2005, Perilaku Organisasi, Refika Aditama, Bandung

Nitisemito, A.S. 2000, Wawasan Sumber Daya Manusia, Jakarta: Psutaka Utama Grafiti

Nugraheni, M.D 2009, Hubungan Antara Beban Kerja dengan Tingkat Kelelahan, Padang Working Paper Series, 3 November

Rivai, Veithzal, 2006, Manajemen Sumber Daya Manusia Untuk Perusahaan, Dari Teori ke Praktek, PT. Raja Grafindo Persada, Jakarta.

Sedarmayanti, 2001, Sumber Daya Manusia dan Produktivitas Kerja, Bandung : Yogyakarta

Journal SNA VII Solo, 15-16 September 2005 Aida Ainul dkk "Pengaruh Sistem Pengukuran Kinerja, Sistem Reward, dan Profit Center Terhadap Hubungan Antara Total Quality Management Dengan Kinerja Manajer STIE Malangkucecwara, Malang 